\title{
In vitro confrontation of Trichoderma spp. isolates with phytopathogenic and non-phytopathogenic fungi
}

\author{
Milton Luiz da Paz Lima ${ }^{1}$, Maria Cristina Araújo Vaz ${ }^{1}$, Aline Suelen da Silva ${ }^{1}$, Karoliny de \\ Almeida Souza ${ }^{1}$, Gabriel Isaias Lee Tuñon ${ }^{2}$
}

\author{
${ }^{1}$ Instituto Federal Goiano - IF Goiano, Campus Urutaí, Urutaí, Goiás, Brasil. E-mail: fitolima@ gmail.com, \\ cristinaaraujo1994@hotmail.com, alinee.ssilva@ hotmail.com, karolinydealmeida@gmail.com, \\ ${ }^{2}$ Universidade Federal de Sergipe, São Cristóvão, Sergipe, Brasil. E-mail: drgleet@hotmail.com
}

Recebido: 10/12/2015; Aceito: 30/03/2016.

\begin{abstract}
The aim of this study was the confrontation of Trichoderma spp. with pathogenic and non-pathogenic fungi. The Trichoderma spp. and filamentous fungi (Fusarium solani, Alternaria sp., Colletotrichum gloeosporioides, and Aspergillus niger) were transferred to potato-dextrose-agar (PDA). The confrontation was performed using Petri dishes inoculated with mycelial disks in opposite position $(9 \mathrm{~mm})$ of Trichoderma spp. and filamentous fungi. After inoculation the plates remained under $25^{\circ} \mathrm{C}$ regime to 12 hours light for a period of seven days. After this period was evaluated qualitatively according to the scale of Bell et al. (1982), which consists of the suitability scores for the area percentage of the culture medium under expression of antagonism. The isolate of C. gloeosporioides (jatropha) was isolated which had statistically slightly inhibited growth by Trichoderma spp., Unlike the isolated Alternaria sp. (parsley) was isolated micelial fungi suffered the most antagonism. Statistically the Trichoderma isolate derived from pineapple promoted the highest antagonistic activity against isolates of pathogenic fungi tested, being a candidate for use in biocontrol.
\end{abstract}

Palavras-chave: plant, biological control, antagonism.

\section{Confronto in vitro de isolados Trichoderma spp. com fungos fitopatogênicos e não fitopatogênicos}

\section{RESUMO}

O objetivo deste trabalho foi realizar o confrontamento de isolados de Trichoderma spp. com fungos fitopatogênicos e não fitopatogênicos. Os isolados de Trichoderma spp. e de fungos filamentosos (Alternaria sp., Aspergillus niger, Bipolaris sp., Colletotrichum gloeosporioides e Fusarium solani) foram repicados em meio batata-dextrose-ágar (BDA). O confrontamento foi realizado utilizando placas de Petri, sendo inoculado em posições opostas discos de micélio $(9 \mathrm{~mm})$ de Trichoderma spp. e fungos filamentosos. Após a inoculação as placas permaneceram sob regime de $25 \mathrm{oC}$, à 12 horas de luz, por um período de sete dias. Após este período avaliou-se qualitativamente de acordo com a Escala de Bell, que consiste na adequação de notas para a porcentagem de área do meio de cultura sob de expressão do antagonismo. O isolado de C. gloeosporioides (pinhão manso) foi o isolado que estatisticamente teve seu crescimento pouco inibido pelos isolados de Trichoderma spp., ao contrário do isolado de Alternaria sp. (salsa) foi o isolado filamentoso que mais sofreu antagonismo. Estatisticamente o isolado de Trichoderma oriundos de abacaxi promoveu a maior atividade antagonista contra os isolados de fungos fitopatogênicos testados, sendo um candidato para uso no biocontrole

Key words: planta, controle biológico, antagonismo. 


\section{Introduction}

Fungi belonging to the genus Trichoderma sp. Pers. (1794) have significant economic importance for agriculture, for its use as a biological control agent of many cultivated plants, and also acting in promoting growth by inducing plant resistance to diseases (MOHAMED; HAGGAG, 2006). This fungus has the ability to degrade cell walls from other fungi using their enzymes, as well as the ability to produce antifungal substances. Such survival strategies make them competitive and proliferating in the rhizosphere (RESENDE et al., 2004; SAMUELS, 2006; BELL et al., 1982; CHET et al., 1997).

The 297 species of Trichoderma already described (INDEX FUNGORUM, 2015) are opportunistic, symbionts of plant roots, large producers of antibiotics (KUMAR et al., 2012), strong soil competitors, saprophytic agents (MOREIRA; SIQUEIRA, 2006), and many of these species are antagonists of other fungi and bacteria, and that includes plant pathogens, with their morphological structures (AMORIM; PASCHOLATI, 2011), which are hardly attacked by other microorganisms (BEDENDO et al., 2011).

These fungi have several ways of interacting like antibiosis, hyperparasitism, competition and growth promotion (MELO, 1996). Lorito et al. (1993) point out that these characteristics are essential for their use as biocontrol agents.

Biological control methods should be based on the selection of antagonistic microorganisms and may be in vitro or in vivo. In vitro tests allow us to recognize the growth and the mechanisms of action, which facilitates the observation of antagonistic interactions between the fungus and the plant pathogen (LIU et al., 2009; LOUZADA et al, 2009; CARVALHO et al., 2011)

Biocontrol can be made indirectly through competition for spaces and nutrients absorption niches by promoting growth in plants, activating defense mechanisms, production of antibiotics or by direct mycopredatism (AGRIOS, 1997; AMORIM et al., 2011).

The biocontrol process depends not only on the antagonist but on the types of crops and environmental conditions such as nutrient availability, $\mathrm{pH}$, temperature and humidity. The activation mechanism is connected to the production of metabolites and other specific compounds as plant growth, hydrolytic enzymes, antibiotics, and permeases C and N (BENITEZ et al., 2004).

Phytopathogenic microorganisms have coexisted with plants since the beginning of agriculture, causing economic damage and losses. Traditional methods to control these pathogens has been the use of chemical pesticides and fungicides, which has caused drastic environmental impacts. One of the most promising ways of achieving the reduction of the use of these chemicals until a future replacement is the use of biological control agents (ACBs) (HOWELL, 2002; ZIMAND et al., 1996).

The search for more sustainable alternatives for the exploitation of natural resources (agriculture) makes the replacement of chemical control tactics by technically appropriate options, economically viable and socially acceptable (MACEDO, 2000). There are 55 registered commercial products in the world that have as active ingredient strains of Trichoderma spp. representing an improvement and expansion of control possibilities using biological control tools (BETTIOL et al., 2012).

The use of biological products against pathogens has been widely studied (KUMAR et al., 2012; CARVALHO et al., 2011; LIU et al., 2009; LOBO JUNIOR et al., 2009; LOUZADA et al, 2009; HOITINK et al., 2006; FOSTER, 1950), because these can reduce the human actions of conventional agriculture, allowing for a more sustainable system of agricultural cultivation. The use of biocontrol agents reduces this environmental impact by the biodegradability and the no aggression of the environment (BETTIOL et al., 2012).

Most commercial products with Trichoderma spp. as active ingredient are being released or in registration phase at the Ministry of Agriculture of Brazil (MAPA, 2014). Hence, the importance of this antagonist as a sustainable alternative to regular use and long-term action to control plant pathogenic fungi.

The objective of this research was to evaluate the in vitro antagonism by Trichoderma isolates on pathogenic and non-pathogenic fungi.

\section{Material and Methods}

The tests were performed in 2014 in the Microbiology and Plant Pathology Laboratory at the Federal Institute of Goiás, Campus Urutaí, Urutaí-GO, using isolates belonging to Mycological Reference Collection.

\subsection{Preparation and incubation of isolated filamentous fungi}

Fourteen isolates belonging to Mycological Reference Collection were used in this study. These isolates had different hosts as a source of origin. The isolates that were maintained on silica gel were transferred to Petri dishes containing potato-dextroseagar (PDA) to obtain patterns cultures, being 7-10 days of growth under conditions of $25^{\circ} \mathrm{C}$ and photoperiod of 12 hours of light. The Trichoderma isolates are listed in Table 1. During the pairing were used as positive control, two commercial isolates of Trichoderma (SC Trichodermil $1306^{\circledR}$ and Quality $\mathrm{WG}^{\circledR}$ ), also listed in 
Table 1. The matrices dishes of Trichoderma were cultured, and then disks of $9 \mathrm{~mm}$ diameter were cut out to be deposited next to the edges of the Petri plate containing PDA culture medium.

Table 1. List of Trichoderma isolates and yours origin host using this experiment*

\begin{tabular}{ll}
\hline Number. & Origin host by Trichoderma isolates \\
\hline 1 & Soy (cod. ND) \\
3 & Cotton (cod. ND) \\
4 & Pineapple (cod. 589) \\
5 & Eucaliptus (cod. ND) \\
6 & Algodãozinho (cod. 210) \\
7 & Corn (cod. 15) \\
8 & Jackfruit (cod. ND) \\
9 & "Guach palm (cod. ND) \\
10 & "Araticumzinho" (cod. 215) \\
11 & Ficus (cód. 208) \\
12 & "Sucupira" (cod. 563) \\
13 & $\begin{array}{l}\text { Trichoderma asperellum (cod. 597) } \\
\text { Trichoderma harzianum (líquido - Trichodermil }\end{array}$ \\
14 & SC1306 ${ }^{\circledR}$ (cod. 588) \\
\hline Cod. ND isolate without register in Collection; Cod. number \\
represent de number registered in collection.
\end{tabular}

\subsection{Preparation and incubation of isolates filamentous} fungi

In order to obtain matrices, monosporic cultures in PDA medium were peaked from: a) Fusarium solani peach palm (Code 607); b) Alternaria sp. - parsley (Code 593.); c) Colletotrichum gloeosporioides Jatropha (without register); d) C. gloeosporioides peach palm (Code 067).; e) Bipolaris spp. - braquiaria, f) Aspergillus niger - jack bean (Code 377). The first four of these isolates are phytopathogenic and last one is non-pathogenic. These fungal strains served as matrices for delivery of mycelium, and after incubation for a period of 7-10 days at $25{ }^{\circ} \mathrm{C}$ under a photoperiod of 12 hours, disks were cut and delivered on the opposite side of a Petri plate containing PDA medium, consisting of two mycelia discs, an antagonist (Trichoderma spp.) and other filamentous fungus.

\subsection{In vitro pairing test between mycelial fungi}

The confrontation was performed using mycelium disks, except for the Aspergillus niger isolate, which used the method of "Direct Attach" - (ALFENAS; MAFIA, 2007) for of the opposing plates to Trichoderma isolate. The experiment consisted of two replicates represented by 14 isolates of Trichoderma spp., matched with five strains of phytopathogenic and non-phytopathogenic fungi, being a completely randomized design, represented by 140 experimental units, or 140 Petri dishes containing combinations of Trichoderma isolates and filamentous fungi.

The experiment was evaluated using the scale of Bell et al. (1982) for analyzing the proportion of antagonism between two paired fungi in culture medium, which was represented by grade 1, when Trichoderma pathogen grows completely over the covering surface of the medium; grade 2 when Trichoderma covered at least two thirds of the surface of the culture medium; grade 3 when Trichoderma and pathogen colonizing each half of the petri dish, with no dominance of microorganisms; grade 4 when the pathogen colonizes at least $2 / 3$ of the surface of the culture medium, but Trichoderma resists colonization; and grade 5, the pathogen grows over Trichoderma and occupies the entire surface of the culture medium.

\subsection{Data analysis}

Data analysis consisted in qualitative interpretation of notes and the frequency of repetitions which have ratings in different grades analyzed by phytopathogenic and non-phytopathogenic fungi (Figure 1) and frequency rating of antagonism between the pairs of isolates (Figure 3), and the use of factorial ANOVA hypothesis testing factor 1 types of filamentous fungi and factor 2 source hosts of Trichoderma isolates and mean comparison by Tukey test of the values of antagonism notes generated from the scale of Bell et al. (1982). The values of the notes when they had normal distribution were transformed by $\sqrt{ }(x+10)$.

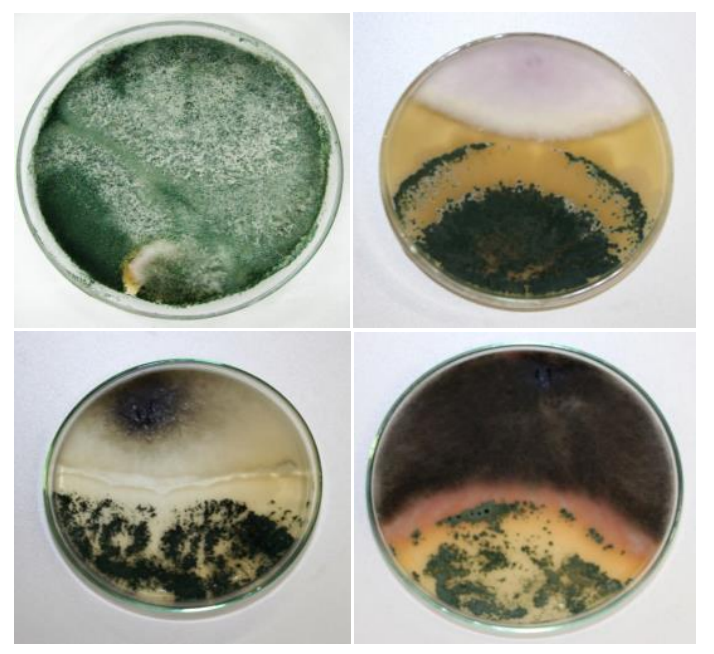

Figure 1. Example growth and different confrontation classified according Bell scale (Bell et al., 1982). Note 1. The Trichoderma sp. isolate grow up grown completely over the filamentous fungus covering the surface of the medium; Note 2. Trichoderma sp. isolate covered at least two thirds of the surface of the culture medium; Note 3. The Trichoderma sp. isolate and filamentous fungi colonized each half of the Petri dish, with no dominance; Note 4 . The filamentous fungus colonized at least $2 / 3$ of the surface of the culture medium, wherein the Trichoderma sp. resists colonization. 


\section{Results and Discussion}

Although belonging to the same species, both Colletotrichum gloeosporioides isolates showed statistically different behavior from each other, being the isolate from jatropha that presented more aggressive to the micelial growth of Trichoderma (Figure 2). Isolates from peach palm statistically suffered the most antagonistic effect, but the Alternaria sp. isolate from salsa was statistically most affected by the tested Trichoderma isolates (Figure 2).

The Trichoderma isolates from milkweed, pineapple and eucalyptus showed a statistically higher antagonistic activity against the phytopathogenic fungi tested (Figure 2), which are important candidates for use in field tests for the identification of antagonist effect efficiency. Under the experimental conditions, commercial Trichoderma isolates and isolates from cotton, "araticunzinho", ficus, corn and soy showed the minorantagonistic effects, or are not candidates for effective control of in vitro growth of filamentous fungi (Figure 2).

Isolates of Fusarium sp. and Bipolaris sp. had their growth strongly inhibited by Trichoderma spp. This is equivalent, when considering the area occupied in the culture medium by Trichodema was $66.6 \%$ (44.4\% for Fusarium sp.) hence inhibiting the growth of the phytopathogen. As for Trichoderma from milkweed and Fusarium sp. from peach palm, the antagonist grew $100 \%$ of the area, totally inhibiting the growth of the phytopathogen.

As for Trichoderma come from milkweed and Fusarium sp. come from peach palm, the antagonist grew by $100 \%$ of the area totally inhibiting the growth of the pathogen.
Isolated Bipolaris sp. from braquiaria and Trichoderma sp. occupied $66.6 \%$ of the culture medium, inhibiting the growth of the phytopathogen, after verifying the original evaluation marks antagonism. Differently, Trichoderma sp. derived from eucalyptus and pineapple, grew $100 \%$ of the area, inhibiting the full growth of the phytopathogen.

When analyzing horizontally the interactions (Table 2) of the filamentous fungi isolates, we observed there was no significant difference between Colletotrichum gloeosporioides (Jatropha), C. gloeosporioides (peach palm), Fusarium sp. (peach palm); being the opposite for others. As for Bipolaris sp. from braquiaria and Trichoderma sp. (pineapple), Trichoderma sp. (milkweed), Trichoderma sp. (eucalyptus), Trichoderma sp. ("guatambú-do-cerrado") they showed statistically higher antagonistic effect against phytopathogenic fungi. For Aspergillus niger combinations showed statistically higher antagonistic effects.

The isolate A. niger derived jack bean, a fungus considered a weak parasite (AMORIM; PASCHOLATI, 2011) derived, demonstrated a variable antagonistic interaction (original data) with the tested Trichoderma isolates, behavior not found for phytopathogenic fungi tested. Highlighting the variations of antagonism, Trichoderma sp. grew $66,6 \%$ in the surface of culture medium in most pairings, inhibiting the growth of $A$. niger and Alternaria sp.

Isolated called Trichoderma Solid isolated from commercial product Qualiti $\mathrm{WG}^{\circledR}$ showed a variation in their antagonism, where $A$. niger derived from jack bean colonized $66.6 \%$ of plaque inhibiting Trichoderma action that resisted colonization.

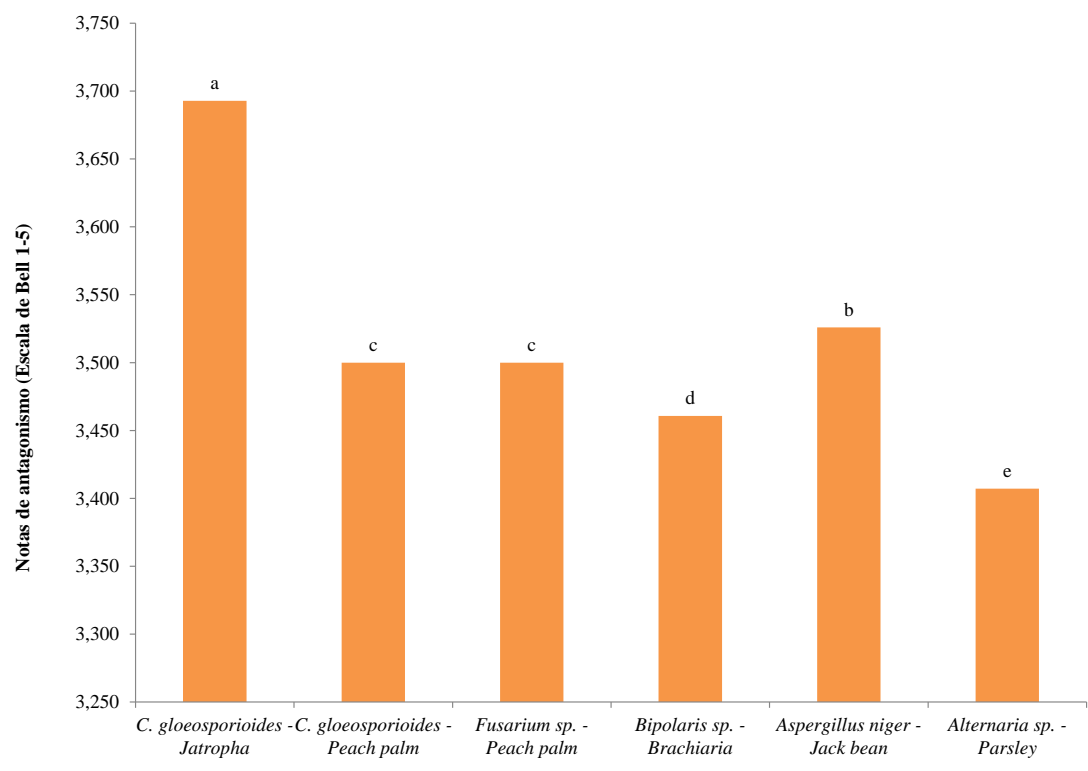

Figure 2: Average of the transformed $(\sqrt{ } \mathrm{x}+10)$ of notes by antagonism of pathogenic and non-pathogenic fungi studied. (Bars followed by the same letter in Tukey test did not differ in the probability of $5 \%$ ). 

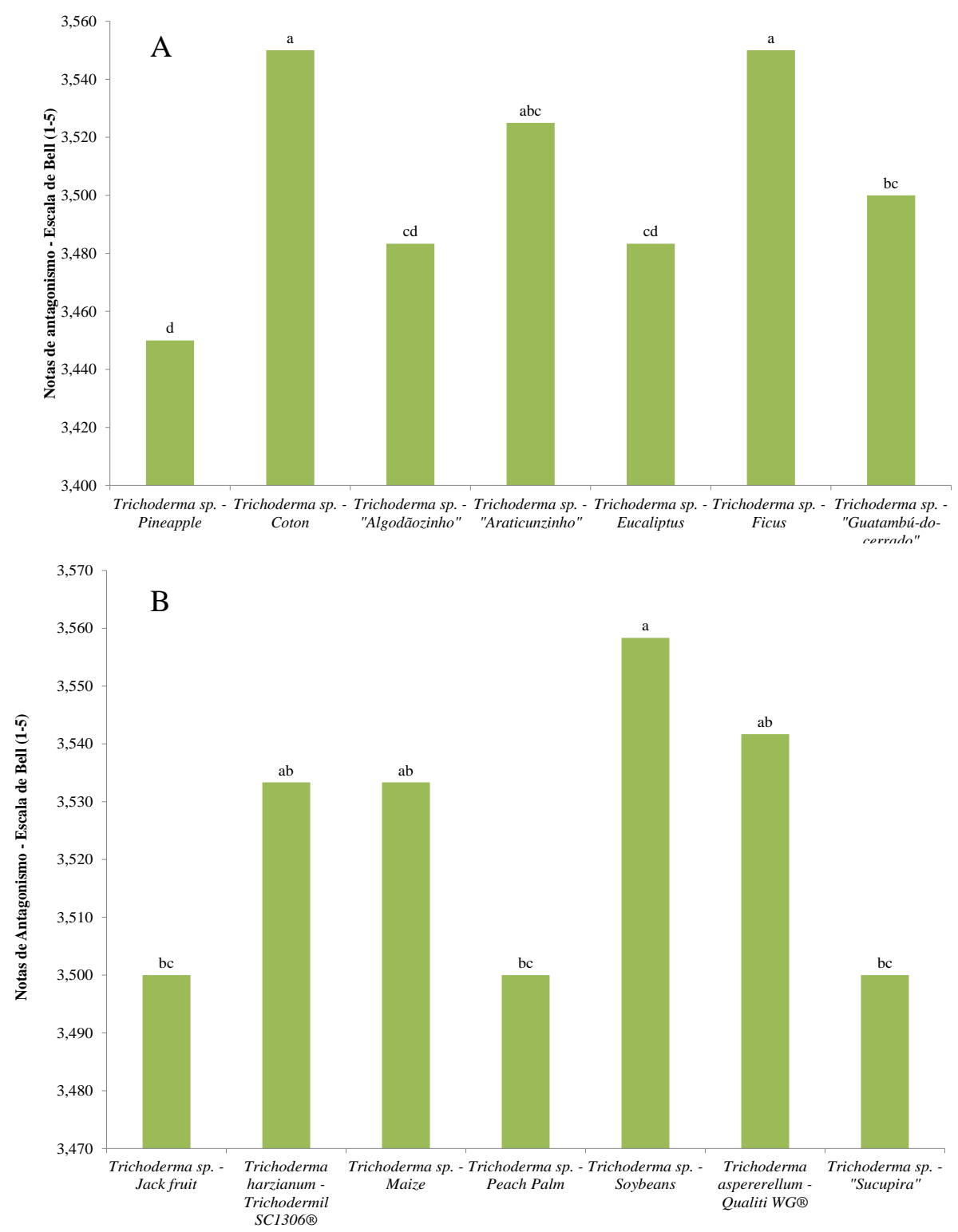

Figure 3. Average of the transformed notes $(\sqrt{ } \mathrm{x}+10)$ antagonism of all isolates of Trichoderma spp. used for comparison (A and B representing a continuation of the data). Values followed by the same letter do not differ in the Tukey test at $5 \%$ probability.

Trichoderma by formulation solid isolated from the commercial product in formulation solid Qualiti WG® showed a variation in its antagonism where A. niger derived from jack bean, colonized $66.6 \%$ of the plate, thus inhibiting the action of Trichoderma that resisted colonization.

With regard to Trichoderma sp. from pineapple, fícus, "araticunzinho", eucalyptus, Trichoderma formulation liquid (Trichodermil SC1306 ${ }^{\circledR}$ ), soybean, Trichoderma formulation solid (Qualiti $\mathrm{WG}^{\circledR}$ ), maize and cotton occupied a surface area of $66.6 \%$ through the plate culture and $33.3 \%$ were colonized by Alternaria sp.

Antagonism of Trichoderma spp. is explained by the production of broad spectrum antibiotics, such as gliotoxin, viridin, trichodermina, suzucacilina, alamethicin and dermadina, which have the ability to inhibit the growth of other fungi (DENNIS; WEBSTER, 1971).

In addition to antibiotics, the microorganisms produce enzymes such as cellulase and hemicellulase, lignocellulolytic materials which degrade and cause lysis in the cell wall of pathogenic fungi (MELO, 1996).

Most Trichoderma spp. expanded on the plate surface and any combination or repetition was classified by grade 5 , which is the score given when filamentous fungus grows on the entire surface of the culture medium by preventing the growth of Trichoderma spp. The Trichoderma isolates sold and marketed (named solid $\mathrm{T}$ and $\mathrm{T}$ net) did not express or had highlighted the antagonism.

There was no better Trichoderma spp. isolate with antagonistic effect on Colletotrichum come from jatropha and peach palm. 
Table 2. Averages transformed interaction $(\sqrt{ } \mathrm{x}+10)$ of the factors types of pathogens and types of Trichoderma*

\begin{tabular}{|c|c|c|c|c|c|c|c|}
\hline Trichoderma sp. & Pineapple & Cotton & Algodãozinho & Araticunzinho & Eucalyptus & Ficus & $\begin{array}{l}\text { Guatambu-do- } \\
\text { cerrado }\end{array}$ \\
\hline \multicolumn{8}{|l|}{ Plant pathogen } \\
\hline $\begin{array}{l}\text { Colletotrichum gloeosporioides- } \\
\text { Jatropha }\end{array}$ & $3,70 \mathrm{aA}$ & $3,70 \mathrm{aA}$ & $3,70 \mathrm{aA}$ & $3,65 \mathrm{aA}$ & $3,70 \mathrm{aA}$ & $3,70 \mathrm{aA}$ & $3,70 \mathrm{aA}$ \\
\hline $\begin{array}{l}\text { Colletotrichum gloeosporioides- } \\
\text { Peach palm }\end{array}$ & $3,50 \mathrm{bA}$ & $3,50 \mathrm{cA}$ & $3,50 \mathrm{cA}$ & $3,50 \mathrm{bA}$ & $3,50 \mathrm{bA}$ & $3,50 \mathrm{cA}$ & $3,50 \mathrm{bA}$ \\
\hline Fusarium sp.- Peach palm & $3,50 \mathrm{bA}$ & $3,50 \mathrm{cA}$ & $3,50 \mathrm{cA}$ & $3,50 \mathrm{bA}$ & $3,50 \mathrm{bA}$ & $3,50 \mathrm{cA}$ & $3,50 \mathrm{bA}$ \\
\hline Bipolaris sp.-Braquiária & $3,30 \mathrm{~dB}$ & $3,50 \mathrm{cA}$ & $3,30 \mathrm{~dB}$ & $3,50 \mathrm{Aa}$ & $3,30 \mathrm{~dB}$ & $3,50 \mathrm{bA}$ & $3,50 \mathrm{bA}$ \\
\hline Aspergillus Níger-Jack bean & $3,40 \mathrm{cB}$ & $3,60 \mathrm{bA}$ & $3,60 \mathrm{bA}$ & $3,50 \mathrm{bAB}$ & $3,50 \mathrm{bAB}$ & $3,60 \mathrm{bA}$ & $3,50 \mathrm{bAB}$ \\
\hline Alternaria sp.- Parsley & $3,30 \mathrm{~dB}$ & $3,50 \mathrm{cA}$ & $3,30 \mathrm{~dB}$ & $3,50 \mathrm{bA}$ & $3,40 \mathrm{cAB}$ & $3,50 \mathrm{cA}$ & $3,30 \mathrm{cB}$ \\
\hline \multicolumn{8}{|l|}{ Continuation } \\
\hline Trichoderma sp. & Jackfruit & $\begin{array}{l}\text { Harzianun.- } \\
\text { Trichodermil } \\
\text { SC 1306® }\end{array}$ & Corn & Peach palm & Soybean & $\begin{array}{l}\text { Asperellum- } \\
{\text { Qualiti } \mathrm{WG}^{\circledR}}\end{array}$ & (B) "Sucupira" \\
\hline \multicolumn{8}{|l|}{ Plant pathogen } \\
\hline $\begin{array}{l}\text { Colletotrichum gloeosporioides- } \\
\text { Jatropha }\end{array}$ & $3,70 \mathrm{aA}$ & $3,70 \mathrm{aA}$ & $3,70 \mathrm{aA}$ & $3,70 \mathrm{aA}$ & $3,70 \mathrm{aA}$ & $3,65 \mathrm{aA}$ & $3,70 \mathrm{aA}$ \\
\hline $\begin{array}{l}\text { Colletotrichum gloeosporioides- } \\
\text { Peach palm }\end{array}$ & $3,50 \mathrm{bA}$ & $3,50 \mathrm{bA}$ & $3,50 \mathrm{bA}$ & $3,50 \mathrm{bA}$ & $3,50 \mathrm{cA}$ & $3,50 \mathrm{bA}$ & $3,50 \mathrm{bA}$ \\
\hline Fusarium sp.- Peach palm & $3,50 \mathrm{bA}$ & $3,50 \mathrm{bA}$ & $3,50 \mathrm{bA}$ & $3,50 \mathrm{bA}$ & $3,50 \mathrm{cA}$ & $3,50 \mathrm{bA}$ & $3,50 \mathrm{bA}$ \\
\hline Bipolaris sp.-Braquiária & $3,50 \mathrm{bA}$ & $3,50 \mathrm{bA}$ & $3,50 \mathrm{bA}$ & $3,50 \mathrm{bA}$ & $3,55 \mathrm{bcA}$ & $3,50 \mathrm{bA}$ & $3,50 \mathrm{bA}$ \\
\hline Aspergillus Níger-Jack bean & $3,50 \mathrm{bAB}$ & $3,50 \mathrm{bAB}$ & $3,50 \mathrm{bAB}$ & $3,50 \mathrm{bAB}$ & $3,60 \mathrm{bA}$ & $3,60 \mathrm{aA}$ & $3,50 \mathrm{bAB}$ \\
\hline Alternaria sp.- Parsley & $3,30 \mathrm{cB}$ & $3,50 \mathrm{bA}$ & $3,50 \mathrm{bA}$ & $3,30 \mathrm{cB}$ & $3,50 \mathrm{cA}$ & $3,50 \mathrm{ba}$ & $3,30 \mathrm{cB}$ \\
\hline
\end{tabular}

*Averages following lowercase in columns followed by the same letter do not differ by Tukey test at 5\% probability; Medium uppercase in columns followed by the same letter do not differ by Tukey test at $5 \%$ probability.

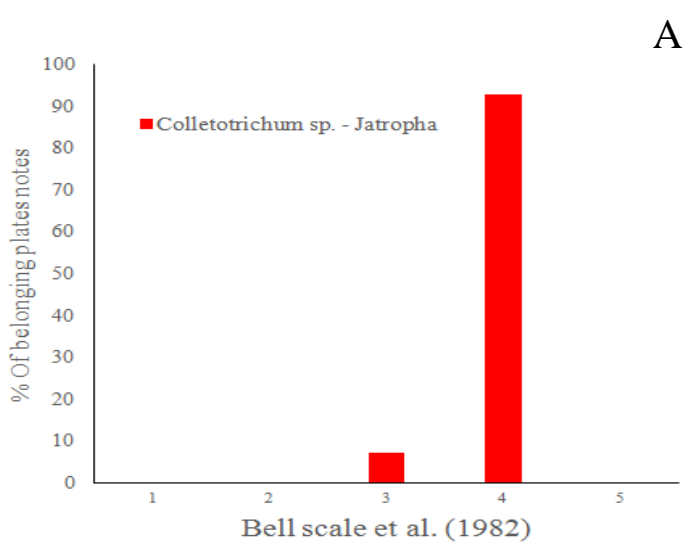

$\mathrm{C}$

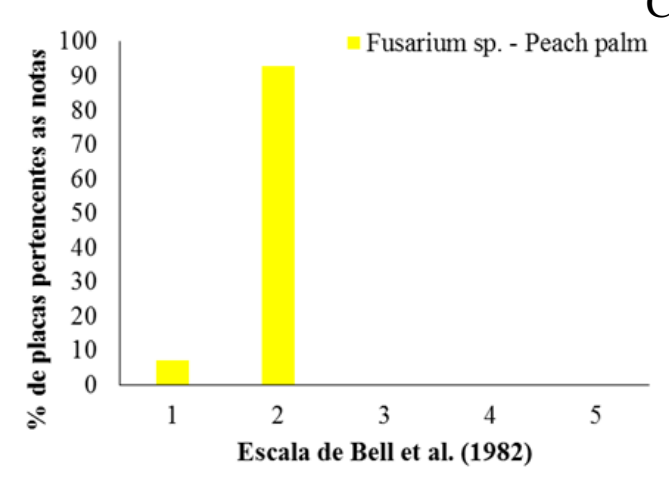

A

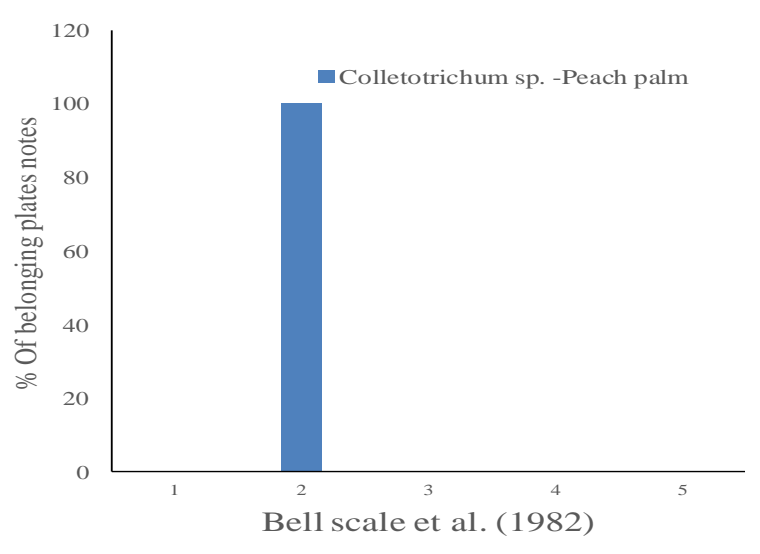

$\mathrm{D}$

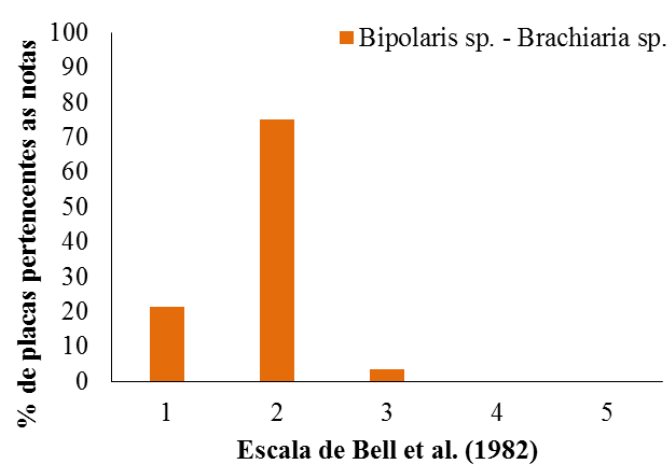



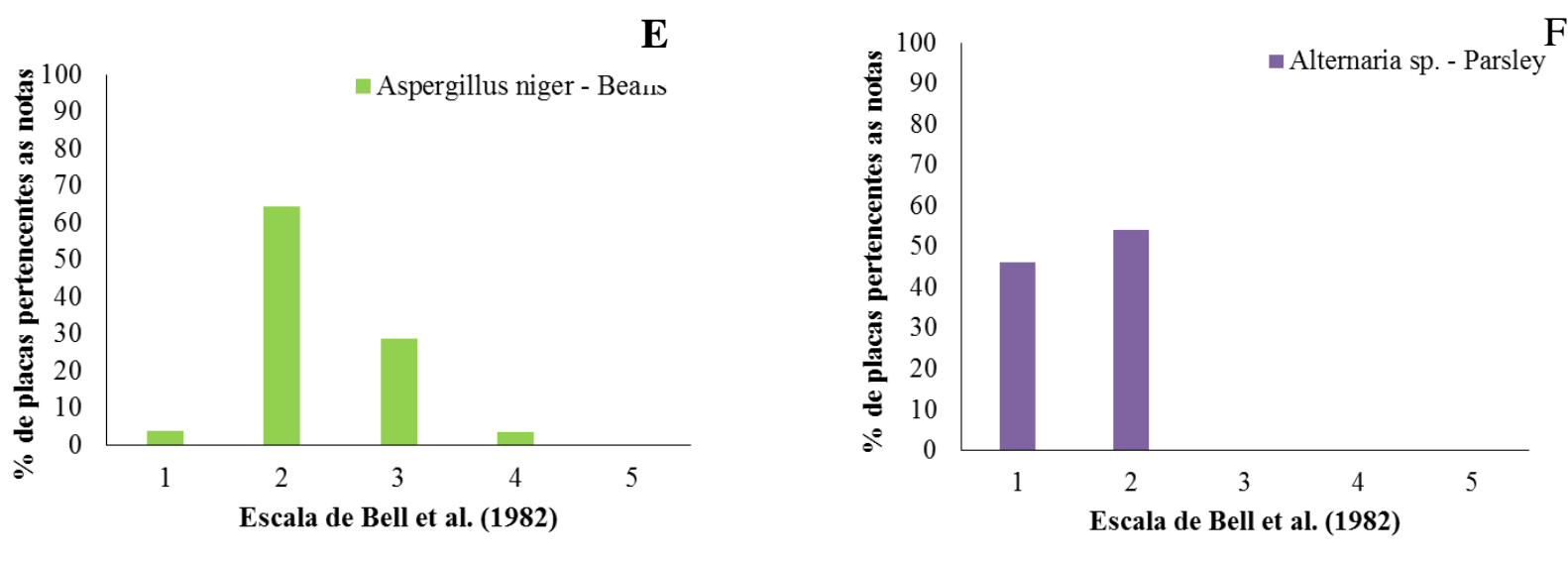

Figure 4. Percentage of antagonistic response classes according to the range of Bell et al. (1982) for the different pathogenic and non-pathogenic fungi. A. Colletotrichum sp. Jatropha, B. Colletorichum in Peach palm, C. Fusarium sp. in Peach Palm, D. Bipolaris sp. in Brachiaria sp., E. Aspergillus niger in beans, F. Alternaria sp. in Parsley.

\section{Conclusions}

Trichoderma isolates from "algodãozinho", pineapple and eucalyptus showed higher antagonistic activity against the tested phytopathogenic fungi.

There was no better isolate from Trichoderma spp. with antagonistic effect on Colletotrichum come from jatropha and peach palm.

For the Fusarium isolate from peach palm, the best isolate of Trichoderma sp. with antagonistic effect came from "algodãozinho".

For Bipolaris isolate from braquiaria, the best isolate of Trichoderma sp. with antagonistic effect came from pineapple and eucalyptus.

For Aspergillus niger derived from jack bean, the best Trichoderma sp. with antagonistic effect came from pineapple.

For Alternaria sp. from parsley, the best Trichoderma sp. with antagonistic effects we as isolated from pineapple.

For Alternaria isolate from parsley was the most susceptible to the antagonism promoted by Trichoderma spp.

\section{References}

AGRIOS, G.N. Plant pathology. 4 ed. San Diego-CA: Academic Press, 1997. 635 p.

ALFENAS, A. C.; MAFIA, R. G. Métodos em Fitopatologia. Viçosa. Ed. UFV. 382p. 2007.

AMORIM, L.; PASCHOLATI, S. F. Ciclos das relações patógeno-hospedeiro. In: AMORIM, L.; REZENDE, J. A. M.; BERGAMIN FILHO, A. Manual de Fitopatologia: Princípios e Conceitos. 4. ed. São Paulo-SP: Agronômica Ceres, 2011. 59-100 p.
AMORIM, L.; REZENDE, J. A. M.; BERGAMIN FILHO, A. Manual de Fitopatologia: Princípios e Conceitos. 4. ed . São Paulo-SP: Agronômica Ceres, 2011. 704 p.

BEDENDO, I. P.; MASSOLA JUNIOR, N. S.; AMORIM, L. Controles cultural, físico e biológico de doenças de plantas. In: AMORIM, L.; REZENDE, J. A. M.; BERGAMIN FILHO, A. Manual de fitopatologia. 4. ed. São Paulo-SP: Agronômica Ceres, 2011. 367-388 p.

BELL, D. K..; WELLS, H. D.; MARKHAM, C. R. In vitro antagonism of Trichoderma species against six fungal plant pathogens. Phytopathology, Saint Paul-US, v. 72, n. 4, p. 379-382, 1982.

BENITÉZ, T.; RINCÓN, A.M.; LIMÓN, M. C.; CODÓN, A. C. Biocontrol mechanisms of Trichoderma strains. International Microbiology, Madrid-ES, v. 7, n. 4, p. 249260, 2004.

BETTIOL, W.; MORANDI, M. A. B.; PINTO, Z. V.; PAULA JÚNIOR, T. J.; CORRÊA, É. B.; MOURA, A. B.; LUCON, C. M. M.; COSTA, J. C. B.; BEZERRA, J. L. Produtos Comerciais à Base de Agentes de Biocontrole de Doenças de Plantas. Jaguariúna-SP: Embrapa Meio Ambiente, 2012, 150 p. (Documento 88).

CARVALHO, D. D. C.; MELLO, S. C. M.; LOBO JUNIOR, M.; SILVA, M. C. Control of Fusarium oxysporum f. sp. phaseoli in vitro and on seeds and growth promotion of common bean in early stages by Trichoderma harzianum. Tropical Plant Pathology, Brasília-DF, v. 36, n.1, p. 36-42, 2011.

CHET, I.; INBAR, J.; HADAR, I. Fungal antagonists and mycoparasites. In: WICKLOW, D. T.; SODERSTROM, B. The mycota IV: Environmental and microbial relationships. 2. ed. Berlim-DE: Springer-Verlag, 1997. p. 165-184.

DENNIS, C.; WEBSTER, J. Antagonistic properties of species groups of Trichoderma. 1- Production of non volatile metabolites. Transactions of the British Mycological Society, London, v. 57, p. 25-39, 1971. 
FOSTER, R. Inativação do vírus do mosaico comum do fumo pelo filtrado de culturas de Trichoderma sp. Bragantia, Campinas-SP, v. 10, n. 5, p. 139- 148, 1950.

HOITINK, H. A. J.; MADDEN, L.V.; DORRANCE, A. E. Systemic resistance induced by Trichoderma spp: interactions between the host, the pathogen, the Biocontrol agent, and soil organic matter quality. Phytopatology, Saint Paul-US, v. 96, n. 2, p. 186-189, 2006.

HOWELL, C. R. Cotton seedling pre-emergence damping-off incited by Rhizopus oryzae and Pythium spp. and its biological control with Trichoderma spp. Phytopathology, Saint PaulUS, v. 92, n. 2, p.177-180, 2002.

INDEX FUNGORUM. Banco de dados de taxonomia de fungos. Disponível em:< http://www.indexfungorum.org/names/Names.asp>, acessado em 10 e março de 2016.

KUMAR, K.; AMARESAN, N.; BHAGAT, S.; MADHURI, $\mathrm{K}$. Isolation and characterization of Trichoderma spp. for antagonistic activity against root rot and foliar pathogens. Indian Journal of Microbiology, India-IN, v. 52, n.2, p. 137144, 2012.

LIU, L. N.; ZHANG, J. Z.; XU, T. Histopathological studies of sclerotia of Rhizoctonia solani parasitized by the EGFP transformant of Trichoderma virens. Letters in Applied Microbiology, Hangzhou-CN, v. 49, n. 6, p. 745-750, 2009.

LOBO JUNIOR, M.; GERALDINE, A. M.; CARVALHO, D. D. C. Controle biológico de patógenos habitantes do solo com Trichoderma spp. na cultura do Feijoeiro. Santo Antônio de Goiás-GO: Embrapa Arroz e Feijão, 2009, 4p. (Circular técnica 85).

LORITO, M.; HARMAN, G. E.; HAYES, C. K. BROADWAY, R. M. TRONSMO, A.; WOO, S. L. PIETRO, A. Chitinolytic enzymes produced by Trichoderma harzianum: antifungal activity of purified endochitinase and chitobiosibase. Phytopathology, Saint Paul-US, v. 83, n. 3, p. 302-307, 1993.

LOUZADA, G. A. S.; CARVALHO, D. D. C.; MELLO, S. C. M.; LOBO JUNIOR, M.; MARTINS, I.; BRAÚNA, L. M.
Antagonist potential of Trichoderma spp. from distinct agricultural ecosystems against Sclerotinia sclerotiorum and Fusarium solani. Biota Neotropica, Campinas-SP, v. 9, n. 3, p. 145-149, 2009.

MACEDO, R. L. G.; VENTURIN, N.; OLIVEIRA, T. K.; FURTADO, S. C. Caracterização e manejo dos principais sistemas silviagrícolas. In: MACEDO, R. L. G. Princípios básicos para o manejo sustentável de sistemas agroflorestais. LavrasMG: UFLA: FAEPE, 2000. p. 37-93.

MAPA. MINISTÉRIO DA AGRICULTURA, PECUÁRIA E ABASTECIMENTO. Registro de Produtos, 2014: BRASÍLIA-DF: MAPA, 2014. Disponível em: http://www.agricultura.gov.br/comunicacao/noticias/2014/06/ mapa-lanca-sistema-de-registro-de-estabelecimentos-eproduto. Acesso em: 10 fev. 2015.

MELO, I. S. Trichoderma e Gliocladium como bioprotetores de plantas. Revisão Anual de Patologia de Plantas, Passo Fundo-RS, v. 4, n. 1, p. 261-295, 1996.

MOHAMED, H. A. L. A.; HAGGAG, W. M. Biocontrol potential of salinity tolerant mutants of Trichoderma harzianum against Fusarium oxysporum. Brazilian Jounal Microbiology, São Paulo-SP, v. 37, n. 2, p. 181-191, 2006.

MOREIRA, F. M. S.; SIQUEIRA, J. O. Microbiologia e Bioquímica do solo. 2. ed. Lavras-MG: UFLA, 2006. 730 p.

RESENDE, M. L.; OLIVEIRA, J. A.; GUIMARÃES, R. M.; VON, R. G. P.; VIEIRA, A. R. Inoculação de sementes de milho utilizando o Trichoderma harzianum como promotor de crescimento. Ciência Agrotécnica, Lavras-MG, v. 28, n.4, p. 793-798, 2004.

SAMUELS, G. J. Trichoderma: Systematics, the sexual state, and ecology. Phytopathology, Saint Paul-US, v. 96, n. 2, p.195-206, 2006.

ZIMAND, G.; ELAD, Y.; CHET, I. Effect of Trichoderma harzianum on Botrytis cinerea pathogenicity. Phytopathology, Saint Paul-US, v. 86, n. 11, p. 1255-1260, 1996. 